\title{
Effect of Hypocholesteremic Compounds on Bacterial Multiplication
}

\author{
By S. AARONSON AND LUCIA FULCO \\ Haskins Laboratories, New York, N.Y. IOOI7, and Biology Department, \\ Queens College, City University of New York, Flushing, N. Y. I 1367
}

(Accepted for publication I August 1967)

\begin{abstract}
SUMMARY
Hypocholesteremic compounds, triparanol, SKF 525-A, SKF 330I-A, SKF I6467-A, inhibited the multiplication of some bacteria and ascomycetes; phycomycetes were not inhibited. Gram-positive bacteria were most sensitive to these compounds. Dimethyl or diethyl aminoethanol and SKF 23I4, compounds resembling the major moieties of the SKF compounds, were not inhibitory alone or together; the whole molecule was necessary for inhibition. Inhibition by triparanol of the multiplication of several Gram-positive bacteria was annulled by albumin and ergosterol; oleic acid and squalene were mostly inactive.
\end{abstract}

\section{INTRODUCTION}

Compounds which inhibit steroid metabolism in mammals ('hypocholesteremics') inhibit the multiplication of a wide variety of micro-organisms, especially Grampositive bacteria (Aaronson, 1965; Martin-Smith \& Sugrue, 1964; Smith, Shay \& Doorenbas, 1963). We have examined the effect on bacterial multiplication of several related hypocholesteremic compounds to determine $(a)$ whether the Gram-positive bacteria are most sensitive; $(b)$ the active moiety of the inhibitory compounds; $(c)$ compounds which annul the inhibition; $(d)$ the potential of these compounds as antibacterial compounds; $(e)$ whether the hypocholesteremic compounds can be used to study bacterial metabolism, especially the role of steroids in bacterial metabolism.

\section{METHODS}

Micro-organisms from the collection of the Biology Department, Queens College, New York, were used. For disc assay, Whatman no. 50 filter-pad discs $(0.6 \mathrm{~cm}$. diam.) were soaked in solutions of the test compound at the concentration indicated, dried, and autoclaved. Bacteria were grown on nutrient agar; fungi on Sabouraud's glucose agar. Cultures in triplicate were incubated at $25^{\circ}$ for 2 days or until they showed good growth over the surface of the Petri dish. Triparanol (I-[ $p$-(4-diethylaminoethoxy)phenyl]-I-( $p$-tolyl)-2- $p$-chlorophenylethanol) was supplied by Dr F. J. Murray (W. S. Merrell, Cincinanti, Ohio); the SKF compounds by Dr W. L. Holmes (Smith Kline and French Laboratories, Philadelphia, $\mathrm{Pa}$.). All other chemicals were bought from commercial sources. Triparanol, SKF-23I4, oleic acid, squalene, and ergosterol were dissolved in $95 \%$ ethanol in water. Other compounds were dissolved in water. 
Table I. Inhibition of bacterial multiplication by hypocholesteremic compounds

\begin{tabular}{|c|c|c|c|c|c|c|}
\hline \multirow{3}{*}{ Bacteria } & \multirow{3}{*}{ Triparanol } & \multicolumn{3}{|c|}{ SKF compounds* } & \multicolumn{2}{|c|}{$\begin{array}{l}\text { Amino- } \\
\text { ethanols }\end{array}$} \\
\hline & & $525-\mathrm{A}$ & 330I-A & I $6467-A$ & 2314 & \\
\hline & & \multicolumn{3}{|c|}{ Size of zone of inhibition $(\mathrm{cm})$} & & \\
\hline Aerobacter aerogenes & 0 & $I \cdot 2 \pm 0 \cdot 2$ & $2 \cdot 1 \pm 0 \cdot 2$ & $I \cdot 7 \pm 0.2$ & 0 & 0 \\
\hline Escherichia coli & 0 & $\overline{0}$ & $\overline{0}$ & 0 & 0 & 0 \\
\hline Proteus mirabilis & 0 & $I \cdot I \pm 0 \cdot 2$ & $I \cdot 5 \pm 0 \cdot 1$ & 0 & o & 0 \\
\hline Pseudomonas putida & 0 & 0 & $I \cdot I \pm 0 \cdot I$ & 0 & 0 & 0 \\
\hline$P$. reptilia & 0 & $I \cdot 0 \pm 0 \cdot I$ & $I \cdot 8 \pm 0 \cdot I$ & $0.8 \pm 0.1$ & 0 & 0 \\
\hline P. vulgaris & 0 & 0 & $I \cdot 8 \pm 0 \cdot 2$ & $I \cdot 4 \pm 0 \cdot 1$ & 0 & 0 \\
\hline \multicolumn{7}{|l|}{ Gram-positive } \\
\hline Bacillus cereus & $0.8 \pm 0.1$ & $I \cdot 0 \pm 0 \cdot 2$ & $1 \cdot 8 \pm 0$ & $0.8 \pm 0.1$ & 0 & 0 \\
\hline B. circulans & $1 \cdot 4 \pm 0.2$ & $1 \cdot 8 \pm 0 \cdot 1$ & $3 \cdot I \pm 0 \cdot 1$ & $2 \cdot 1 \pm 0.6$ & 0 & 0 \\
\hline B. fusiformis & $1 \cdot 0 \pm 0.3$ & $I \cdot 0 \pm 0 \cdot I$ & $I \cdot 9 \pm 0 \cdot 4$ & $0.8 \pm 0$ & 0 & 0 \\
\hline B. mycoides & $I \cdot 1 \pm 0 \cdot 3$ & $1 \cdot 9 \pm 0.4$ & $1 \cdot 9 \pm 0.5$ & $I \cdot 4 \pm 0.6$ & 0 & 0 \\
\hline B. subtilis & $I \cdot I \pm 0.6$ & $2 \cdot 0 \pm 0 \cdot I$ & $2 \cdot 7 \pm 0 \cdot 2$ & $0.9 \pm 0.1$ & 0 & 0 \\
\hline Micrococcus luteus & $1 \cdot 8 \pm 0.2$ & $\mathrm{I} \cdot 8 \pm 0 \cdot \mathrm{I}$ & $2.6 \pm 0.4$ & $I \cdot 5 \pm 0 \cdot 3$ & 0 & 0 \\
\hline M. lysodeikticus & $0.8 \pm 0.2$ & $I \cdot 9 \pm 0 \cdot I$ & $2 \cdot 2 \pm 0 \cdot 2$ & $0.7 \pm 0.1$ & 0 & 0 \\
\hline$M$. roseus & $2 \cdot 0 \pm 0.3$ & $I \cdot 6 \pm 0 \cdot I$ & $2 \cdot I \pm 0 \cdot 3$ & $0.9 \pm 0 . I$ & 0 & 0 \\
\hline M. sodonensis & $I \cdot 5 \pm 0.3$ & $1 \cdot 9 \pm 0.5$ & $2 \cdot 2 \pm 0 \cdot 7$ & $0.8 \pm 0.1$ & 0 & 0 \\
\hline Mycobacterium phlei & $2 \cdot 0 \pm 0.4$ & $2.9 \pm 0.6$ & $3 \cdot 3 \pm 0 \cdot 5$ & $I \cdot 6 \pm 0.6$ & 0 & 0 \\
\hline My. smegmatis & $I \cdot I \pm 0 \cdot 2$ & $2 \cdot 0 \pm 0.5$ & $2 \cdot 4 \pm 0.3$ & $I \cdot 2 \pm 0 \cdot 2$ & 0 & o \\
\hline Sarcina flava & $I \cdot I \pm 0 \cdot 3$ & $I \cdot 7 \pm 0.4$ & $2 \cdot I \pm 0 \cdot I$ & $I \cdot I \pm 0.2$ & 0 & 0 \\
\hline Staphylococcus albus & $0.9 \pm 0.2$ & $0.8 \pm 0.1$ & $I \cdot 5 \pm 0 \cdot I$ & $\mathbf{I} \cdot \mathbf{I} \pm 0$ & 0 & 0 \\
\hline S. aureus & $I \cdot 2 \pm 0 \cdot 2$ & $I \cdot 3 \pm 0 \cdot I$ & $I \cdot 6 \pm 0 \cdot 1$ & 0 & 0 & 0 \\
\hline S. citreus & $1 \cdot 5 \pm 0.5$ & $1 \cdot 3 \pm 0 \cdot 2$ & $2 \cdot 0 \pm I \cdot O$ & 0 & 0 & 0 \\
\hline
\end{tabular}

* Discs soaked in solution (O.I M) of compound.

† Dimethylaminoethanol, diethylaminoethanol, dimethyl-3-aminopropanol, diethyl-3-aminopropanol, dimethyl-2-arninopropanol, diethyl-I-aminopropanol.

Table 2. Effect of concentration on inhibition

\begin{tabular}{|c|c|c|c|c|}
\hline \multirow{2}{*}{ Compound } & \multirow{2}{*}{$\begin{array}{l}\text { Discs soaked } \\
\text { in conc. } \\
\text { (M) }\end{array}$} & $\begin{array}{l}\text { Bacillus } \\
\text { subtilis } \\
\text { Siz }\end{array}$ & $\begin{array}{l}\text { Micrococcus } \\
\text { sodonensis } \\
\text { one of inhibi }\end{array}$ & $\begin{array}{l}\text { Mycobacterium } \\
\text { smegmatis } \\
(\mathrm{cm})\end{array}$ \\
\hline & & & & \\
\hline Triparanol & $\begin{array}{l}0.1 \\
0.05 \\
0.01 \\
0.005 \\
0.001\end{array}$ & $\begin{array}{c}I \cdot 2 \pm 0.2 \\
0.9 \pm 0 . I \\
I \cdot 2 \pm 0 . I \\
I \cdot I \pm 0.2 \\
0\end{array}$ & $\begin{array}{l}I \cdot 5 \pm 0.2 \\
I \cdot 4 \pm 0.6 \\
I \cdot 7 \pm 0.3 \\
I \cdot 5 \pm 0.3 \\
0.9 \pm 0.2\end{array}$ & $\begin{array}{l}2 \cdot 3 \pm 0.2 \\
2.0 \pm 0.2 \\
2 \cdot 2 \pm 0.2 \\
2.4 \pm 0.2 \\
1 \cdot 4 \pm 0.4\end{array}$ \\
\hline SKF 525-A & $\begin{array}{l}0.1 \\
0.05 \\
0.01 \\
0.005 \\
0.001\end{array}$ & $\begin{array}{c}I \cdot 8 \pm 0.2 \\
I \cdot 4 \pm 0.3 \\
I \cdot 2 \pm 0.5 \\
0 \\
0\end{array}$ & $\begin{array}{c}I \cdot 9 \pm 0.2 \\
I \cdot 2 \pm 0.3 \\
0 \\
0 \\
0\end{array}$ & $\begin{array}{c}2 \cdot 3 \pm 0.5 \\
2 \cdot I \pm 0 . I \\
I \cdot 3 \pm 0.2 \\
0.9 \pm 0.1 \\
0\end{array}$ \\
\hline SKF 330I-A & $\begin{array}{l}0.1 \\
0.05 \\
0.01 \\
0.005 \\
0.001\end{array}$ & $\begin{array}{c}2.4 \pm 0.8 \\
2.1 \pm 0.6 \\
0 \\
0 \\
0\end{array}$ & $\begin{array}{l}2.0 \pm 0.1 \\
1.5 \pm 0.4 \\
0.7 \pm 0.1 \\
0.7 \pm 0 \\
0.7 \pm 0\end{array}$ & $\begin{array}{c}3.6 \pm 0.4 \\
2.8 \pm 0.3 \\
I \cdot 0 \pm 0.2 \\
0 \\
0\end{array}$ \\
\hline
\end{tabular}




\section{RESULTS}

Earlier work (Aaronson, 1965) with two hypocholesteremic compounds (triparanol, benzmalecene) showed that Gram-positive bacteria were more sensitive than Gramnegative bacteria. Triparanol again inhibited only Gram-positive bacteria (present work) while the SKF compounds (525-A, 330I-A, I6467-A) inhibited Gram-positive and Gram-negative bacteria; the Gram-positive bacteria were more sensitive to the SKF compounds (Table I). The bacteria sensitive to the hypocholesteremic compounds varied in sensitivity to the several compounds (Table 2). As with triparanol (Aaronson, I965) several of the SKF compounds inhibited ascomycetes but not phycomycetes (Table 3). The inhibitory SKF compounds have aromatic and aliphatic parts (Fig. I). Neither the aromatic moiety (SKF 23I4) nor the aliphatic moiety (dimethyl- or diethyl-aminoethanols or their analogues) inhibited bacterial multiplica-

Table 3. Inhibition of fungal multiplication by hypocholesteremic compounds

\begin{tabular}{|c|c|c|c|c|c|c|}
\hline \multirow{3}{*}{ Fungi } & & \multicolumn{3}{|c|}{ SKF compounds* } & \multirow{3}{*}{2314} & \multirow{3}{*}{$\begin{array}{l}\text { Amino- } \\
\text { ethanols }\end{array}$} \\
\hline & Triparanol & $525-\mathrm{A}$ & $3301-A$ & I $6467-\mathrm{A}$ & & \\
\hline & \multicolumn{4}{|c|}{ Size of zone of inhibition $(\mathrm{cm})$} & & \\
\hline $\begin{array}{l}\text { Ascomycetes } \\
\text { Hansenula saturans }\end{array}$ & $I \cdot 3 \pm 0 . I$ & $1.0 \pm 0 . I$ & $0.9 \pm 0.3$ & 0 & 0 & 0 \\
\hline Neurospora crassa & $1 \cdot 5 \pm 0 \cdot 1$ & $\overline{0}$ & 0 & 0 & 0 & o \\
\hline Penicillium roqueforti & $1 \cdot 6 \pm 0 \cdot 3$ & 0 & 0 & 0 & 0 & o \\
\hline Rhodotorula rubra & $I \cdot 6 \pm 0 \cdot I$ & $\mathrm{I} \cdot \mathrm{O} \pm 0 \cdot \mathrm{I}$ & $0.9 \pm 0.2$ & 0 & 0 & 0 \\
\hline \multicolumn{7}{|l|}{ Phycomycetes } \\
\hline Aspergillus niger & 0 & 0 & 0 & 0 & 0 & 0 \\
\hline Synecophalotium nigricans & 0 & 0 & 0 & 0 & 0 & 0 \\
\hline
\end{tabular}

* Discs soaked in $0 \cdot \mathbf{I} \mathrm{M}$ solution of compound.

Table 4. Annulment of inhibition by triparanol

\begin{tabular}{|c|c|c|c|c|c|}
\hline & Triparanol & $\begin{array}{c}\text { Triparanol } \\
+ \\
\text { albumin }\end{array}$ & $\begin{array}{c}\text { Triparanol } \\
+ \\
\text { oleic acid }\end{array}$ & $\begin{array}{c}\text { Triparanol } \\
+ \\
\text { squalene }\end{array}$ & $\begin{array}{c}\text { Triparanol } \\
+ \\
\text { ergosterol }\end{array}$ \\
\hline Gram-positive & \multicolumn{5}{|c|}{ Size of zone of inhibition (cm.) } \\
\hline Bacillus cereus & $0.8 \pm 0.1$ & 0 & $0.9 \pm 0$ & . & . \\
\hline B. circulans & $I \cdot 4 \pm 0 \cdot 2$ & $0.8 \pm 0.1$ & $\mathrm{I} \cdot 8 \pm 0 \cdot \mathrm{I}$ & $1 \cdot 6 \pm 0.2$ & - \\
\hline B. fusiformis & $1 \cdot 0 \pm 0.3$ & 0 & $I \cdot 3 \pm 0 \cdot 2$ & . & o \\
\hline B. mycoides & $I \cdot I \pm 0 \cdot 3$ & 0 & $0.9 \pm 0.2$ & . & $0.7 \pm 0$ \\
\hline B. subtilis & $I \cdot I \pm 0.6$ & o & $0.9 \pm 0.2$ & $I \cdot 2 \pm 0 \cdot 4$ & 0 \\
\hline Micrococcus luteus & $1 \cdot 8 \pm 0 \cdot 2$ & o & $2 \cdot 0 \pm 0.8$ & $I \cdot 4 \pm 0 \cdot 1$ & $0 \cdot 7 \pm 0 \cdot 1$ \\
\hline M. lysodeikticus & $0.8 \pm 0.2$ & 0 & $I \cdot I \pm 0 \cdot 2$ & $0.7 \pm 0$ & o \\
\hline$M$. roseus & $2 \cdot 0 \pm 0 \cdot 3$ & $0.8 \pm 0$ & . & $I \cdot 7 \pm 0.2$ & o \\
\hline M. sodonensis & $1 \cdot 5 \pm 0.3$ & 0 & . & $I \cdot 3 \pm 0 \cdot I$ & $0.7 \pm 0.1$ \\
\hline Mycobacterium phlei & $2 \cdot 0 \pm 0.4$ & $0.8 \pm 0.2$ & $I \cdot 8 \pm 0 \cdot 2$ & $2 \cdot 7 \pm 0 \cdot 3$ & $0.9 \pm 0$ \\
\hline My. smegmatis & $I \cdot I \pm 0 \cdot 2$ & 0 & $I \cdot O \pm 0 \cdot I$ & $I \cdot 8 \pm 0 \cdot 4$ & $1 \cdot 0 \pm 0 \cdot 1$ \\
\hline Sarcina flava & $I \cdot I \pm 0 \cdot 3$ & o & $I \cdot I \pm 0 \cdot I$ & $I \cdot I \pm 0.2$ & 0 \\
\hline Staphylococcus albus & $0.9 \pm 0.2$ & o & 0 & $I \cdot O \pm 0 \cdot I$ & . \\
\hline S. aureus & $I \cdot 2 \pm 0 \cdot 2$ & $0.7 \pm 0$ & $I \cdot I \pm 0 \cdot I$ & . & $0.8 \pm 0$ \\
\hline S. citreus & $I \cdot 5 \pm 0.5$ & 0 & $I .9 \pm 0.7$ & $2 \cdot 0 \pm 0.2$ & . \\
\hline
\end{tabular}

Concentrations used: triparanol, $0.1 \mathrm{M}$; oleic acid, $0 . \mathrm{I} \mathrm{M}$; squalene, $0 . \mathrm{I} \mathrm{M}$; ergosterol, 0.0 I M; bovine serum albumin, $0.2 \%$. 


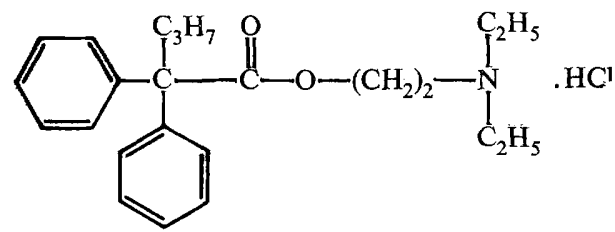

$\beta$-Diethylaminoethyl-diphenylpropyl acetate. HCl (SKF 525-A)<smiles>CCCCC(C(=O)O)(c1ccccc1)c1ccccc1</smiles>

Diphenylpropylacetic acid (SKF 2314)<smiles>CCCCC(COCCN(C)C)(c1ccccc1)c1ccccc1</smiles>

2,2-Diphenyl-1-( $\beta$-dimethylaminoethoxy)pentane. $\mathrm{HCl}$ (SKF 3301-A)<smiles>CCCCCN(C)CCNC(=O)C(CC)(c1ccccc1)c1ccccc1</smiles>

$\beta$-Dimethylaminoethylamino-diphenylpropylacetate. HCl (SKF 16467-A)<smiles>CCN(CC)CCOc1ccc(C(O)(Cc2ccc(Cl)cc2)c2ccc(C)cc2)cc1</smiles>

1-[4-Diethylaminoethoxy)phenyl]-1-( $p$-tolyl)-2-( $p$-chlorophenyl) ethanol (Triparanol)

Fig. I. The structure of several hypocholesteremic compounds.

tion at $0 \cdot I \mathrm{M}$, a concentration at which the other SKF compounds were inhibitory. Discs containing SKF 2314 or diethylaminoethanol added on top of each other or discs soaked in SKF 23I4 + diethylaminoethanol were inactive.

In previous work with a photosynthetic bacterium oleic acid, ergosterol and squalene annulled the inhibition by triparanol (Aaronson, 1964). Oleic acid was not as effective 
in preventing the inhibition of multiplication by triparanol as were albumin or ergosterol, while squalene seemed to enhance the inhibition by triparanol (Table 4). Alone, none of these lipids or albumin was inhibitory at the concentrations used.

\section{DISCUSSION}

Gram-positive bacteria are more inhibited by hypocholesteremic compounds than are Gram-negative bacteria (Aaronson, 1965; Martin-Smith \& Sugrue, 1964; Smith et al. 1963). The results here with the SKF compounds (Table I) bear this out. Of the several microbial groups exposed to the SKF compounds, bacteria, ascomycetes, protozoa (Aaronson, 1966) but not phycomycetes were sensitive. These results are like those obtained with triparanol and benzmalecene (Aaronson, 1965). While the combined aliphatic and aromatic moieties, i.e. SKF 525-A, SKF 330I-A, seem necessary for bacterial inhibition (see Table I), these compounds acted strikingly differently with the eucaryotic phytoflagellate Ochromonas danica (Aaronson, 1966) where the aromatic moiety, i.e. SKF-23I4, but not the aliphatic moiety, i.e. diethylaminoethanol, was as inhibitory as SKF-525A. The sensitivity of bacteria to a disc soaked in as little as I $\mathrm{mM}$ of the compound and to a variety of hypocholesteremic compounds, i.e. azasteroids (Martin-Smith \& Sugrue, 1964; Smith et al. 1963), triparanol and benzmalecene (Aaronson, I965) and SKF 525-A, SKF 330I-A, and SKF I6467-A, implies that these compounds may offer leads to compounds which inhibit pathogenic bacteria, especially the Gram-positive ones, as well as other pathogens.

Several workers have reported that unsaturated fatty acids (e.g. oleic and linoleic acids) inhibit multiplication of Gram-positive but not Gram-negative, bacteria (Kodicek, 1956; Kodicek \& Worden, 1945; McQuillen, 1958). McQuillen (I958) found that this inhibition was prevented by lecithin, several steroids, and $\alpha$-tocopherol for Lactobacillus helveticus, while vitamin $\mathrm{D}_{2}$ annulled the inhibition of $L$. casei by linoleic acid. McQuillen (1958) observed that linoleic acid inhibited the uptake in L. casei of ${ }^{14} \mathrm{C}$-labelled metabolites such as glutamic acid, lysine, glucose, phenylalanine, adenine and uracil in fixed cellular form (proteins of membranes, etc.) but had far less effect on their uptake into the cellular pools. Vitamin $D_{2}$ prevented the inhibition by linoleic acid of the uptake of the compounds into fixed form. Like the inhibition by unsaturated fatty acids, the inhibition of Gram-positive bacteria by triparanol was annulled by ergosterol and also by albumin. While earlier workers did not report on albumin (a well-known annuller of the inhibition of mitochondrial activity by unsaturated fatty acids) it may well be that triparanol (and perhaps other hypocholesteremics) and unsaturated fatty acids inhibit Gram-positive bacteria at the same site, and that these inhibitions are annulled by albumin or steroids. The nature of this site and the reason for the lack of sensitivity of Gram-negative bacteria remain to be determined. It is provocative that steroids annul the inhibition of multiplication by hypocholesteremics in procaryota, which are not supposed to synthesize sterol, while only unsaturated fatty acids annul the inhibition by hypocholesteremics in the eucaryotic Ochromonas, which does synthesize steroids (Aaronson, 1965, 1966).

This work was aided by grants from the City University of New York and the National Institutes of Health, Bethesda, Md., U.S.A. (GM 09I03). 


\section{REFERENCES}

Aaronson, S. (1964). A role for a sterol and a sterol precursor in the bacterium Rhodopseudomonas palustris. J. gen. Microbiol. 37, 225.

AARonson, S. (1965). Inhibition of microbial multiplication by hypocholesteraemic compounds. J. gen. Microbiol. 39, 367.

AARONSON, S. (I966). Study of the cellular action of drugs with protozoa. III. Comparison of the effect of SKF 525-A and related compounds on the multiplication of Ochromonas danica. Biochem. Pharmacol. 15, I24I.

KodiceK, E. (1956). The effect of unsaturated fatty acids, of vitamin D and other sterols on Grampositive bacteria. In Biochemical Problems of Lipids. Ed. by C. Popjak and E. Le Breton, p. 40I. London: Butterworth's Scientific Publications.

KODICEK, E. \& WORDEN, A. N. (I945). The effect of unsaturated fatty acids on Lactobacillus helveticus and other Gram-positive micro-organisms. Biochem. J. 39, 78.

MARTIN-Smith, M. \& Sugrue, M. F. (1964). Biological activity in steroids possessing nitrogen atoms: recent advances. J. Pharm. Pharmacol. 16, 569.

MCQuILlEN, K. (1958). Some aspects of bacterial structure and function: observations on bacterial cell walls, protoplasts and spheroplasts together with a study of the effects of linoleic acid and vitamin $\mathrm{D}_{2}$ on Lactobacillus casei. Proc. 4th int. Congr. Biochem. 13, 406.

Smith, R. F., Shay, D. E. \& Doorenbas, N. V. (1963). Effects of proteins, lipids, and surfactants on the antimicrobial activity of synthetic steroids. Appl. Microbiol. II, 542. 